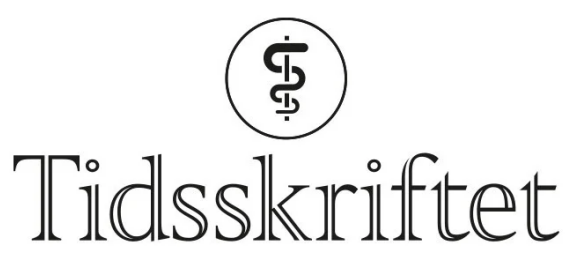

DEN NORSKE LEGEFORENING

\title{
Som man roper i skogen ...
}

LEDER

TORSTEIN VIK

torstein.vik@ntnu.no

Torstein Vik er professor emeritus i barnesykdommer ved NTNU. Han er far til en 46 år gammel utviklingshemmet kvinne.

Forfatteren har fylt ut ICMJE-skjemaet og oppgir ingen interessekonflikter.

\section{Pasientrapporterte erfaringer: Hva vil vi vite, hva får vi vite - og hva bruker vi svarene til?}

Pasienters og pårørendes erfaringer er viktige supplement til andre kvalitetsindikatorer i helsevesenet (1). Et søk i PubMed på «Patient-reported experience outcomes» viser en eksponentiell økning i antallet artikler med dette temaet de siste ti årene. I Norge var man tidlig ute (ㅁ), og på Folkehelseinstituttets hjemmesider finnes en rekke skjemaer som kan benyttes til å undersøke pasienters og pårørendes erfaringer (3). Resultatene viser at norske pasienter og pårørende i store trekk er fornøyd (4믐). Dette er resultater som sikkert leses med tilfredshet av helseadministratorer og politikere.

Spørreundersøkelsen som nå publiseres i Tidsskriftet om erfaringene til foreldre til barn med Downs syndrom, nyanserer dette bildet (7.). Til forskjell fra de ovennevnte studiene der det stilles generelle spørsmål etter sykehusopphold eller polikliniske konsultasjoner, spør Stefferud og medarbeidere om oppfølgingen av barna, og de stiller spørsmål som er spesifikke for barn med Downs syndrom. Forfatterne finner da at bare halvparten av foreldrene til 161 barn var fornøyd med oppfølgingen hos barnelege eller barnehabiliteringstjenesten. Foreldrene var minst fornøyd med oppfølgingen av søvnvansker, pubertet og psykiske vansker, og mest fornøyd med oppfølgingen av medfødte hjertefeil, syn og stoffskifte. Et svært bekymringsfullt funn er at nesten hver femte forelder vurderte at diagnosen Downs syndrom hadde ført til behandlingssvikt.

Forfatterne har ikke benyttet et validert spørreskjema. Ettersom utvalget bare omfatter rundt $12 \%$ av personer med Downs syndrom i den aktuelle aldersgruppen, og at svarene er innhentet fra en interessegruppe gjennom en nettbasert undersøkelse, er risikoen for seleksjonsskjevhet betydelig. Det vil derfor være interessant å få vite om habiliteringstjenester og barneavdelinger kjenner seg igjen i de nevnte resultatene. I så fall er det flere funn som viser at det er rom for forbedring.

I en rapport fra 2020 (4), der man fant at «norske pasienter er stort sett fornøyd med sykehusoppholdet» (5), fikk forhold rundt utskrivning og samhandling de laveste skårene, rundt 6o på en skala fra o (dårligst) til 100 (best). Pasienter som vurderte egen helse som nokså god eller dårlig, var imidlertid mindre tilfreds enn pasienter som vurderte egen 
helse som meget god eller utmerket. Eldre pasienter var mindre fornøyd enn yngre. I en annen studie publisert i 2021 fant forfatterne at $97 \%$ av pårørende var fornøyd med den tverrfaglige utredningen barnet deres hadde fått ved barnehabiliteringene i Finnmark og Troms (ㅁ). Imidlertid fant man også at et relativt høyt antall pårørende var mindre fornøyd med koordineringen av tjenestene. Mye tyder dermed på at pasienter med sammensatte behov ikke er like fornøyd som gjennomsnittspasienten etter et sykehusopphold/poliklinisk utredning med hvordan helsevesenet fungerer som helhet.

\section{«Det hadde vcert virkelig nyttig om pasientrapporterte erfaringer rutinemessig inngikk $i$ evalueringene av store og små endringer $i$ helsevesenet»}

Det hadde vært virkelig nyttig om pasientrapporterte erfaringer rutinemessig inngikk i evalueringene av store og små endringer i helsevesenet. Men er generiske spørreskjemaer egnet til dette formålet? I en systematisk oversiktsartikkel fra 2019 fant man at bare to av 88 spørreskjemaer omfattet helsevesenet som helhet, og bare fire hadde dokumentert evne til å måle endringer etter intervensjoner ( $\underline{8})$. Vil man måle effekten av intervensjoner, er sistnevnte egenskap essensiell. Det må heller ikke foreligge en takeffekt (dvs. at svært mange respondenter gir høyeste skåre), slik tilfellet var for det generiske spørreskjemaet som ble brukt i studien fra Troms og Finnmark (므).

Samhandlingsreformen og sammenslåing av sykehus er eksempler på store omlegginger i helsevesenet. Selv om omleggingene ikke er reversible, kan pasienterfaringer være nyttig for fremtidig planlegging. Eksempler på mindre omlegginger er nedleggelse av mindre fødeavdelinger og kortere liggetid på barselavdelinger. Det er nok enklere å forklare at bedre medisinsk kvalitet veier opp for mulige negative pasienterfaringer ved førstnevnte endring enn sistnevnte.

Uansett hva man vil bruke pasientrapporterte erfaringer til, tyder studien til Stefferud og medarbeidere på at generiske spørreskjemaer bør suppleres med målrettede spørsmål og spørsmål som i større grad tar for seg helsevesenet som helhet. Selv om svarene kanskje ikke blir like behagelige, er dette nødvendig om man ikke vil gå glipp av viktig informasjon.

\section{LITTERATUR}

1. Agency for Healthcare Research and Quality. What Is Patient Experience? https://www.ahrq.gov/cahps/about-cahps/patient-experience/index.html Lest 26.7.2021.

2. Guldvog B, Hofoss D, Pettersen KI et al. PS-RESKVA-pasienttilfredshet i sykehus. Tidsskr Nor Laegeforen 1998; 118: 386-91. [PubMed]

3. Folkehelseinstituttet. Spørreskjemabanken. https://www.fhi.no/kk/brukererfaringer/sporreskjemabanken2/ Lest 16.7.2021.

4. Sjetne IS, Holmboe O. Pasienters erfaringer med norske sykehus i 2019. Metodebeskrivelse og analyser for landet samlet. Oslo: Folkehelseinstituttet, 2020.

https://www.fhi.no/contentassets/1ed1cf501boa43d58415dcbb3ab889e6/metodebeskrivelse-oganalyser-for-landet-samlet.pdf Lest 26.7.2021.

5. Folkehelseinstituttet. Pasientene er stort sett fornøyd med sykehusoppholdet. https://www.fhi.no/nyheter/2020/pasientene-er-stort-sett-fornoyd-med-sykehusoppholdet/ Lest 26.7.2021.

6. Kjærandsen KS, Brøndbo PH, Halvorsen MB. Determinants of caregiver satisfaction with child neurodevelopmental assessment in neuropaediatric clinics. BMC Health Serv Res 2021; 21: 139. [PubMed][CrossRef]

7. Stefferud MJ, Einang AG, Klingenberg C. Erfaringer med helsevesenet blant foreldre til barn med Downs syndrom. Tidsskr Nor Legeforen 2021; 141. doi:10.4045/tidsskr.21.0024. [CrossRef] 
8. Bull C, Byrnes J, Hettiarachchi R et al. A systematic review of the validity and reliability of patientreported experience measures. Health Serv Res 2019; 54: 1023-35. [PubMed][CrossRef]

Publisert: 21. september 2021. Tidsskr Nor Legeforen. DOI:10.4045/tidsskr.21.0553

(C) Tidsskrift for Den norske legeforening 2023. Lastet ned fra tidsskriftet.no 26. april 2023. 